\title{
Comparative analyses of microorganisms from different high- temperature volcanic environments
}

\author{
M.C. Portillo and I. Mt. Cronzalez

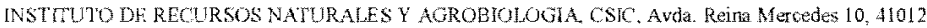 \\ Sevilla, Spain
}

Volcanic enyiroments and the microorganisms thriving in these hostile sites are nostly unknown requiring further studies to understand their paticipation in biological and geochemical cycles. This study presents a comparative analysis of the microrganisms encountered in high temperature environnents from two zeographically distant volcanic environments, located in Canary Islands (Span) and Kamchatka Peninsula (Russian Fedoration)

Snee the isolation and characterization of microoganisms living under extreme conditions (ie. high temperatures) is generaliy diffeult, the use of molecular techieques allows the detectlon of uneultured microrganisms and so a broader approach to study their distribution and role in these enviroments. Both high-tetuperature sites wh temperature between 70 and $95^{\circ} \mathrm{C}$ were sampled in a prelimary study to decipher the tricroerganisms present in these extrme enviroments. The 168 rRNA genes Ware amplined from envirommental DNA and RNA. DNA Ased detection stgests the presence of a microorganism while RVA-based analysis indicated that microotganism is metabolically ative in the given thvironnent. Among the deteoted microorgan wms the Proteobacteria were the nost frequently Cound bacterial group, and others like Aotinobacteria. Fimicutes, Bacteroidetes, and verucomicrobia were signilicant in the studied samples. Inter estingly, neither DNA nor RMA analysis lead to the detection of typical herthem opuilic microonganisins. Bacterial RNA slability at high temperatures was determined and it half-life was around $2-5$ minutes. Thus the presence of mesophiles for moderate themophilest in these high temperature environments might be a result of a high dispersion rate leading to a high number of immigant mictorganisnto these high temperature locations. Consequenty, this study has serious implications on ciment estimates of bacterial diversity, the distribution and dispersal of micromganisms, and a high potential of mictobes for colonizing nuvel enviromentz

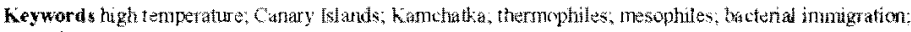
volearic envipuments 